\title{
Author Correction: Enah overexpression is correlated with poor survival and aggressive phenotype in gastric cancer
}

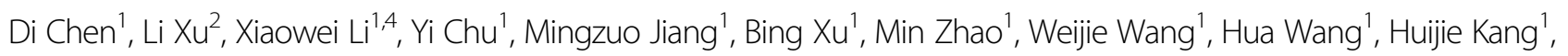
Kai Wang ${ }^{3}$, Kaichun $\mathrm{Wu}^{1}$, Jie Liang ${ }^{1}$ and Gui Ren ${ }^{1}$

\section{Correction to: Cell Death \& Disease 9, 998 (2018); https://doi.org/10.1038/s41419-018-1031-x, published online 24 September 2018}

In the version of this article originally submitted, Fig. $5 j$ included a mismatched image which had been accidentally inserted by the authors during collation of the data. The final data was derived from three independent experiments, and three repetitions for each experiment to ensure the repeatability, reliability and scientificity of the experiment. During this process, the fields overlapped to some extent, giving rise to the mistake. It does not alter any inferences drawn from the data, and the statistical graph is correct. This error has been corrected in both the PDF and HTML versions of the Article.

Published online: 07 May 2019

\footnotetext{
Correspondence: Kaichun Wu (kaicwu@fmmu.edu.cn) or

Jie Liang (liangjie@fmmu.edu.cn) or Gui Ren (renguigz@hotmail.com)

${ }^{1}$ State Key Laboratory of Cancer Biology and Xijing Hospital of Digestive

Diseases, the Air Force Military Medical University, 127 Changle Western Road,

Xi'an, Shaanxi Province 710032, China

2Department of Hematology, People's Liberation Army Center of Hematologic

Disorders, Xijing Hospital, the Air Force Military Medical University, 127 Changle

Western Road, Xi'an, Shaanxi Province 710032, China

${ }^{3}$ Department of Gastroenterology, the 16th Hospital of the People's Liberation

Army of China, 219 Tuanjie South Road, A Letai, Xinjiang Province 836599,

China

${ }^{4}$ Department of Gastroenterology, Navy General Hospital, Beijing 100048,

China

These authors contributed equally: Di Chen, Li Xu, Xiaowei Li, Yi Chu
}

(c) Open Access This article is licensed under a Creative Commons Attribution 4.0 International License, which permits use, sharing, adaptation, distribution and reproduction in any medium or format, as long as you give appropriate credit to the original author(s) and the source, provide a link to the Creative Commons license, and indicate if changes were made. The images or other third party material in this article are included in the article's Creative Commons license, unless indicated otherwise in a credit line to the material. If material is not included in the article's Creative Commons license and your intended use is not permitted by statutory regulation or exceeds the permitted use, you will need to obtain permission directly from the copyright holder. To view a copy of this license, visit http://creativecommons.org/licenses/by/4.0/. 